\title{
Feminisms in Iraq: Beyond the Religious and Secular Divide
}

\section{Zahra Ali}

\begin{abstract}
This article explores feminisms and women's activisms in today's Iraq and highlights the heterogeneity of both their religious and secular expressions in analysing them in relation to each other rather than as distinct. I argue that not only do we need to go beyond the Islamist/secular dichotomy but we need to analyse what's in-between these categories. In order to understand their in-betweenness, Iraqi women's activisms and feminisms have to be examined in their imbricated and complex social, economic and political contexts both discursive and material. I start by reflecting on conceptual considerations regarding the relationships between feminisms, Muslimness, and Islam(s) and examining notions of piety and morality in contemporary Iraq. Then I explore the context and nature of women's social and political activisms in Baghdad, Erbil, and Sulaymaniyah and provide an ethnographically informed examination of the different trends of feminisms and women's political activisms in Iraq and the ways these trends overlap. In doing so I introduce an alternative way of understanding the too often argued secular/Islamist opposition and analyse the relevance and meaning of 'Islamic/Muslim feminisms' in the Iraqi context.
\end{abstract}

Keywords: feminisms, Iraq, women's rights, secularism, Muslim feminisms, Islam, piety

Ali, Zahra. 2019. 'Feminisms in Iraq: Beyond the Religious and Secular Divide.' Gender a výzkum / Gender and Research, Vol. 20, No. 2: 47-67, http://dx.doi.org/10.13060/257065 78.2019.20.2.483.

Since the 1990s, scholarship on women and gender in the Middle East has paid particular attention to the emergence of women's activism within groups and movements affiliated to political Islam or Muslim pietist movements (Ahmed 1992; Deeb 2006; Göle 1993; Karam 1998; Mir-Hosseini 2000; Mahmood 2005). Such literature presents Islamist or Islam-related women's activism as the manifestation of alternative experiences and definitions of modernity within religion and analyses Islamist women's activism and pietist women's movements as separate from or in opposition to secular forms of activism. My argument in this article is that both religious and 
secular expressions of feminisms and women's activisms in Iraq are heterogeneous and need to be analysed in relation to each other rather than as distinct. I argue that not only do we need to go beyond the Islamist/secular dichotomy but we need to emancipate ourselves from these categories and analyse what's in-between ${ }^{1}$ them. I also argue that in order to understand their in-betweenness, Iraqi women's activisms and feminisms have to be examined in their imbricated and complex social, economic, and political contexts, both discursive and material.

This article starts by reflecting on conceptual considerations regarding the relationships between feminisms, Muslimness, and Islam(s) in examining notions of piety and morality in contemporary Iraq. Then I rely on my ethnography of women's social and political groups in Baghdad, Erbil, and Sulaymaniyah ${ }^{2}$ to provide an ethnographically informed examination of the different trends of feminisms in Iraq. I also explore how these different trends overlap and exist in relation to one another, challenging the too often argued secular/lslamist opposition. Finally, I highlight the importance of situating feminisms in Iraq within their broader social, economic, and political contexts.

\section{On Muslimness, Islam(s), and Feminisms}

The emergence of the 'woman question' in the context of the independence - as both a symbol of the progressive aspirations of a Westernised elite and the expression of 'authentic' Muslim/Islamic culture - has been widely analysed. Indeed, feminist/ women's movements in the Middle East emerged within nationalist and antiimperialist struggles (Badran 1995; Jayawardena 1986). Later, the rise of political Islam and its use of the 'woman question' in religious terms can also be read through this post-colonial approach. Since the 1980s, a wide range of research has focused on Islamist discourses on women and crossing between feminist aspirations and Islamism (mostly on Egypt and Iran). On that matter, special attention was drawn to unveiling and veiling processes; a focus that is still very common today (Ahmed 2011). The category 'Islamic feminist' is often put forward as developing an 'endogenous' form of feminism (Mir-Hosseini 2000). Despite its limitations, the merit of this approach

1 For the notion of in-betweenness, I am very grateful to the organisers and participants in the workshop 'Islamic Feminists, Islamist Women, and the Women Between' held in Paris in January 2013 and supervised by Lila Abu-Lughod, Katherine Ewing and Anupama Rao, as part of the project 'Gender, Religion and Law in Muslim Societies', Centre for the Study of Social Difference, Columbia University.

2 I conducted this in-depth ethnography between October 2010 and June 2012, I interviewed more than 80 Iraqi women activists of all ages and social, ethnic, religious, and political backgrounds from across women's groups, organisations and networks mainly in Baghdad and secondarily in Erbil and Sulaymaniyah in Iraqi Kurdistan. 
is its capacity to break past the modern/tradition conceptual framework and place the rise of political Islam within processes of modernisation (Göle 1993; Mir-Hosseini 2000), alongside other studies on Islamism (Burgat 1996, 2005).

Sami Zubaida's critique (2011) of the use of the adjective 'Islamic' highlights the simplistic use of both 'Islam' and the 'West' in contemporary scholarship about the Middle East. In the context of Iraq, Zubaida shows that diverse and multi-layered realities are often portrayed as 'Islamic' despite belonging to different and sometimes competing legacies (Zubaida 1989). In Beyond Islam (2011) Zubaida convincingly recalls that capitalism has been one of the most essential motors of modernity, and the imposition of modernity during colonisation meant the imposition of a capitalist mode of economy that 'Islam' has been accommodating. Zubaida examines how the overemphasis on 'cultural' modes of resistance to modernity, often represented by Islamist movements, can be very misleading, as it considers only its discursive dimension and puts aside its concrete material condition of expression. Indeed, in the analysis of women and feminist activism in Iraq, it is essential to consider both discourses and the material realities in which they are grounded.

In her work on the Egyptian women's movement Al-Ali (2000) proposes to define 'secular-oriented' forms of feminisms as characterised by the acceptance of the separation between religion and politics and stresses that this definition does not necessarily denote 'anti-religious' or 'anti-Islamic' positions. According to Al-Ali, 'secular-oriented women' in Egypt do not support shari'a as the main or sole source of legislation; they refer to civil law and human rights conventions adopted by the UN as frames of reference for their struggle. However, she also highlights the heterogeneity of understandings and manifestations of secularism among Egyptian women activists and the necessity to analyse the continuum between religious and secular beliefs and practices in women's everyday lives, as 'secular-oriented women' in Egypt can also be practicing Muslims (2000: 130). Al-Ali also insists on the necessity to provide a complex reading of the continuum between religious and secular activism, staying away from dichotomous views: 'The very dichotomy of religious versus secular seems rather counterproductive as it only feeds into Islamist conceptualizations of secularists "being against religion"' (2000: 14). Al-Ali highlights how the Egyptian women's movement reflected the social and political postcolonial Egyptian context (2000).

Zakia Salime's research (2011) takes a different approach to the study of secular and Islamist women's rights activisms, analysing the debates around the mudawwana [family law] in Morocco; her work provides a relational, rather than a comparative, ethnographic study of feminist and Islamist women's movement. Salime argues that exploring feminist politics requires, on the one hand, an examination of how the feminist movement has been both enabled and circumscribed by Islamist women's 
activism over the past two decades. On the other hand, such an exploration also entails the identification of the various ways in which feminist movements have shaped the politics of protest among Islamist women. Salime describes these changes as the feminisation of Islamist women and the Islamisation of feminist movements. In the same line, Afsaneh Najmabadi (2000) in the context of postrevolutionary Iran argues that the configurations of Islam, feminism, nationalism, and secularism have been hybridised by two decades of the Islamic Republic in power and thus cannot be analysed through the political paradigms that were dominant and accepted in the past. She insists on the fact that Islam, secularism, nationalism, and feminism are historically defined and in a changing relationship and should be analysed as such.

In line with Niamh Reilly, who proposes that we 'rethink secularism as a feminist principle' (2011), I argue here that the secular itself has to be contextualised and read within a complex framework in order to be understood. Here I argue that both secular and Islamist women's activism reflects the Iraqi social and political context. Akin to Salime's study of the Moroccan women's movement (2011), I explore Iraqi feminisms in relation to one another, not as separate entities, in order to highlight the diversity of both non-religious/secular and religious feminisms and the ways in which they overlap.

\section{On Piety, Morality and Respectability ${ }^{3}$}

Talal Asad's critique and questioning of the religious/secular dichotomy, in his seminal work Formations of the Secular (2003), can be applied to the conservative/progressive dichotomy - firstly because its meaning relies on the context in which it emerges, and secondly because it conforms to different dimensions that are porous as well as ambivalent. It is thus interesting to draw a comparison between pious Iraqi women's discourses on piety, gender, and modernity and Lara Deeb's exploration (2006) of gender and 'public piety' among pious Shi'a women loosely affiliated with Hizbullah in al-Dahiyya (southern Beirut). The comparison with Deeb's research is relevant due to both its theoretical approach and the closeness of the Lebanese context with regards to issues of sectarianism and gender. Deeb considers the definition of modernity to be an unproductive question, arguing that it is far more interesting to explore how pious Shi'a Muslims understand 'being modern' and how they deploy and engage various discourses and ideas about modern-ness. In maintaining an ethnographic

3 This section was inspired and developed with the organisers and participants of the workshop Gendering Faith: Islamist Women Activism, supervised by Muwatin, the Palestinian Institute for the Study of Democracy, and CMI - Chris. Michelsen Institute. 
focus on the ways in which notions of modern-ness and piety are lived, debated, and shaped by 'everyday Islamists', Deeb demonstrates the complexity and underscores the inseparability of religion and politics in the lives of pious Muslims.

Like Mahmood (2005), Deeb rejects approaches that consider Islamist or Islamrelated social and political engagements to be a strategy for coping with or resisting Westernisation; instead, she posits that faith is not merely a façade that hides what is 'really' going on, but that in fact faith is what is going on. She shows that the core of this enchanted modern is a dual emphasis on both material and spiritual progress as necessary to modern-ness. Spiritual progress, in particular, is viewed by pious Shi'as as a necessary component of a viable alternative to the perceived emptiness of modernity, as manifested in the West. Deeb suggests that when religiosity is incorporated into modern-ness in this way, the stakes of being pious change. The dualistic notion of progress and the global political context in which it has emerged have consequences for faith and morality on the personal level and on people's quotidian expressions and experiences of piety. In al-Dahiyya, women's public piety has been incorporated as both necessary to and evidence of the enchanted modern. Deeb argues that looking at these complex daily enmeshments of piety and politics makes it possible to show that Islam is not in the service of politics, nor are politics determined solely by Islam. She argues that it is only by holding both in view, and thus undoing their separation, that a more complete understanding of the pious modern can be grasped.

I concur with Deeb's approach to piety, which is grounded in the context of local and global political, social, and economic dynamics. I am also very much convinced of the importance of considering faith in and of itself, and not reducing it to a political anti-Western reaction or means of contestation, although I do also consider its inherent political dimension. Thus, I argue that Iraqi women's pietism, either Islamist or not, is guided by its own dynamics of faith that are imbricated with notions of politics, either anti-Western or anti-secularist. Interestingly, while still exploring al-Dahiyya, Deeb and Harb (2013) also analyse the relationship between leisure, morality, and geography, complexifying their analysis in a way that is very relevant to my research. By using the concept of 'multiple moral rubrics', they extended their critique of Mahmood's views. Using Schielke's analysis of Muslim youth in Egypt (2009), Deeb and Harb argue that Mahmood's privileging of piety as a 'primary motivator' is problematic. Mahmood's focus on religious piety does not do justice to the complex and often contradictory nature of everyday experiences and oversimplifies the complexities of the daily negotiations of moral practices. Following Schielke's analysis, Deeb and Harb consider that ethical subjectivities are based on the co-existence of various motivations, aims, and identities that can and often do conflict, but are not exclusive opposites. Thus, they define the concept of 
'multiple moral rubrics' as the overlapping of the 'social rubric' (manners, values of social obligation, hierarchies shared across society), 'political-sectarian rubric' (reflecting the conflation of sectarian identity and different moralities associated with politico-sectarian communities), and 'religious rubric' (ideas of piety and religious commitments).

The concept of 'multiple moral rubrics' is very relevant for examining the Iraqi context. The 'social rubric' consists of the behaviours and duties considered part of what is commonly 'done' and 'approved' by society, that which is moral and respectable, which are the products of complex legacies and imaginaries. The 'political-sectarian rubric' is constituted both by local and global political dynamics that ended up with the sectarianisation of Iraqi political life and by the legacies of competitive national imaginaries exacerbated by the US invasion and occupation (Ali 2018). The 'religious rubric' is composed of the different dynamics of faith and religious practices, which obey their own rules and normative ideas and practices. Thus, Iraqi women's notions of what is pious, moral, and respectable are built upon the overlapping of social, political-sectarian, and religious dynamics.

\section{Living and Mobilising in an Occupied and Fragmented Country}

The invasion of Iraq, coupled with the bombing and fighting that occurred between March and May 2003, led to hundreds of thousands of civilian deaths. ${ }^{4}$ After the occupation was established through the CPA and the Iraqi governing councils were set up based on communal quotas, Iraqis' daily lives began to be characterised by violence. The sectarian civil war that continues to haunt the country was the direct result of the CPA's de-Ba'athification campaign, which decommissioned 400,000 Iraqi soldiers and Ba'ath Party members undermining the state, the political marginalisation of the Sunni population, and the establishment of communal identities as the basis of the Iraqi political system (Ismael, Ismael 2015; Arato 2009; Dodge 2005, 2013). The US army's repression of uprisings against the occupation - especially in Fallujah - and the rise of political and party-associated militias benefiting from the power vacuum all took a sectarian shape. The exacerbation of sectarian conflict reached its extreme during the 2006-2007 sectarian war. ${ }^{5}$ This civil war and all the associated events represented the second turning point after 1991 in Iraqi sectarian relations and reorganised society and territory along sectarian lines (Haddad 2014).

4 Estimated according to: The Lancet (2004); Iraq Body Count (www.iraqbodycount.org, last accessed 3 February 2017); and 'Iraq: the Human Cost' (http://web.mit.edu/ humancostiraq/, last accessed 3 February 2017).

5 Between 2006 and 2007, the sectarian civil war claimed at least 1000 lives per week, mostly civilian, and both internally and externally displaced around 2500000 people, according to the UNHCR. 
This fracturing is visible in the division of Baghdad into homogeneously Sunni and Shia neighbourhoods, each separated by checkpoints and concrete walls (Ali 2018; Damluji 2010).

The sectarian dimension of the social retribalisation that started during the economic sanctions in the 1990s was pushed even further in the chaos that followed the invasion. As shown in my research, along with that of others, sectarian violence is gendered (Al-Ali, Pratt 2009; Ali 2018; Ismael, Ismael 2007). Most of the women activists I interviewed, especially public and media figures, have received death threats or been directly targeted by violence, including car bomb attacks in front of their offices or homes. Some had to flee the country, but the majority remain in Baghdad. Some moved into areas controlled by their sect, as their neighbourhoods were attacked by sectarian militias. Ibtihal I., in her early forties, a very active women's rights activist in the Iraqi Women's League (IWL), told me how, in an attempt to kill her in 2007, a group of men placed explosives in front of her house that then exploded. The event occurred after she had received several death threats from conservative Islamist militia groups in the form of phone calls and messages. Fortunately, no one was in the house at the time. Ibtihal recalls the police's incompetence and unwillingness to help her find the perpetrators of the attack and provide her with protection. She describes the atmosphere of Baghdad in 2006-2007 and her feelings about it:

You know, in 2006 and 2007, after 2 pm, the streets of Baghdad were empty. There was no life in Baghdad. The next day, everything opened at 8 am. But people were scared to go out very early or later than $2 \mathrm{pm}$. Violence was everywhere. Armed groups, death threats, militias, the everyday reality was terrible, frightful. Even till today, you know, the value of life is lost in Iraq. Any disagreement between political leaders ends up in street violence. We face death every single day, every Iraqi who leaves his house is not sure that he'll come back alive. Iraq has been transformed into a scene of death. Even when we have moments of joy, we feel that we are stealing these moments, and we then refrain ourselves, saying Allah yesterna [May God protect us]. The worst thig is that we do not even have a state, a government whom we could ask for protection or complain to.

Many neighbourhoods were controlled by foreign soldiers, especially the US army, until 2011, which constituted an important barrier for women who wanted to move about freely and away from the harassing gaze of foreign armed men. In addition to the overall insecurity that led to the deaths of many Iraqi women activists, most of the women I interviewed noticed how the rise of conservative gender norms impacted their dress and ability to move freely in particular neighbourhoods of Baghdad. Today, many areas of the country and the capital are controlled by militias and armed groups 
that are backed by conservative, sectarian Islamist parties, and many women have witnessed or experienced incidents relating to others' or their clothing or behaviour when crossing checkpoints. Christian women activists, too, prefer to wear a loose shawl over their heads when moving between the capital's different neighbourhoods. Many of the women I interviewed described incidents such as hair salons being closed, or car bomb attacks intended to prevent women from driving. More generally, an overwhelming sense of tension has been created by the violence and the dominance of competing armed militias in the streets. This feeling was expressed repeatedly to me: 'Before, we had one Saddam; today we have a Saddam on every street corner.'

Moreover, my ethnographic research shows that the militarisation of Iraqi public spaces has turned Baghdad into a 'city of men': checkpoints, walls, and soldiers in the streets everywhere (Ali 2018). Many places are now inaccessible for women and some places such as cafés, once the pride of riverside Baghdad, are reserved for men after $5 \mathrm{pm}$ in many neighbourhoods in the capital.

The economic sanctions of the 1990s plunged Iraqi society into poverty, destroying its middle class and altering state institutions and services, the education system, and the health sector. In a context of extreme poverty and a survival economy, new forms of patriarchy started to emerge, exacerbating gender norms and relations (Al-Jawaheri 2008; Al-Ali 2007; Ali 2018). In destroying what was left of the Iraqi state and institutions, the invasion and occupation of 2003 carried on the dramatic alteration of the Iraqi social fabric and gave it a sectarian dimension. In 2007, over half of the Iraqi population lived on less than one dollar a day. Acute malnutrition has more than doubled since 2003 , affecting no less than $43 \%$ of all children between the ages of six months and five years. Almost $50 \%$ of all households have been deprived of healthy sanitation facilities. There is a critical lack of medical drugs and equipment, and more than 15,000 doctors have been killed or kidnapped or have fled the country (Sassoon 2012). Even in Baghdad, the state provides a maximum of five hours of electricity per day. The lack of control and stability since 2003 and the privatisation and liberalisation of the economy have caused a drastic increase in the price of staple goods and basic necessities. As a result, the majority of Iraqis are poor, even though they live in an oilrich country. No major plans or policies have been undertaken by the new regime to deal with these issues. The new state's weakness and its inability to provide security and respond to basic needs, such as access to running water, electricity, housing, and employment, along with mismanagement and corruption have pushed Iraqis to rely on alternative sources of protection and service.

From 2003, Iraqi women were at the forefront of social and political activism, as hundreds of women's groups and organisations were created. As the invasion and occupation destroyed the Iraqi state and instituted a sectarian political scene, and as political violence began to rise, women became involved at every level of society. 
US and international networks and funds were dedicated to women's rights and women-related campaigns and initiatives. As a result, most Iraqi women's social and political activisms, with the exception of a few organisations such as the Organisation of Women's Freedom in Iraq (OWFI), have been shaped by these networks of fund such as USAID, UNAMI, UN-Women (previously UNIFEM), UNDP, UN-Habitat, and international NGOs such as the Global Fund for Women, Oxfam, and other European NGOs. I explore the NGOisation of women's activism in my previous work (2018), arguing that it has shaped most Iraqi women's organisations' initiatives and campaigns and had a uniformising effect on their action and discourses. Iraqi women's social and political involvement covers a wide range of activities. Iraqi women activists are involved in democracy and human rights mainstreaming through taw'iyya [awarenessraising] and tathqif [culture-raising] campaigns, which reveals the NGOisation of their activism. However, they are also involved in humanitarian, health, social, and educational work, acting as a substitute for state institutions that are absent or weak. Iraqi women activists are involved in political lobbying around their legal and political rights - mobilising around the adoption of a $25 \%$ quota for women in representative assemblies. Iraqi feminists' most important mobilisation revolves around the Personal Status Code (PSC), a legal frame based on Sunni and Shi'a jurisprudence gathering most of women's legal rights that the Shi'a Islamist political elite seek to turn into a sectarian-based code since 2003 (Ali 2017). Iraqi women are between the 'hammer and the anvil' to use Kandiyoti's term (2007), struggling to keep their basic legal rights gathered in the PSC and to survive in a context lacking security and basic resources.

\section{Iraqi Women's Feminisms}

Like elsewhere, Iraqi women activists have diverse ways of understanding political activism and feminisms. Throughout my ethnographic work in Baghdad, Erbil, and Sulaymaniyah and in the 80 interviews I conducted with Iraqi women activists from across diverse women's groups, organisations, and networks of all ages and social, ethnic, and political backgrounds, I identified several trends of activism for women's rights. I have broken down these trends into four categories, from the most common to the most unique, while bearing in mind that such categories are not exclusive and that they overlap.

\section{Human Rights Feminists}

Human Rights Feminists are the most common phenomenon across the spectrum of Iraqi women activists. This activist trend is very common among women who first got involved in women's civil society organisations after 2003; those who had no prior familiarity with political activism or gender-specific issues. Human Rights Feminists 
often define their activism as 'defending women's rights as a part of human rights' and became involved primarily 'as women' within civil society organisations. Human Rights Feminists cite international human rights conventions and the UN's regime of women's rights, such as CEDAW and SCR 1325, and advocate for the unified PSC to be preserved. These women activists also advocate a reform of the PSC that would 'align Iraqi laws with international conventions of rights', but most remain very general in their stance, taking for granted the division between the public and the private. Thus, when asked to expand on the extent of such reforms, most question Penal Code articles related to ta'dib al-zawja [disciplining the wife], which permit domestic violence and lighten sentences for crimes committed in the 'name of honour'. They also demand abolishing legal requirements for women to have a mahram to travel and a wali al-amr to obtain a passport. Human Rights Feminists also suggest reforming the PSC to penalise marriages contracted outside the court, reinforce a woman's right to divorce, and penalise the excessive use of polygamy.

Most Human Rights Feminists insist on respecting Iraqi/Muslim culture and finding common ground with religious authorities. The focus of their advocacy is on the public domain - for example, the struggle to implement a $25 \%$ quota ${ }^{6}$ for women in representative assemblies and to increase women's participation in the spheres of politics, work, and education. Most of their initiatives relate to notions of 'women's leadership' and 'empowerment', encouraging women to participate in 'democracy building', voting, civil society, and political groups.

Having attended gender mainstreaming courses provided by international NGOs and UN-Women since 2003, Human Rights Feminists tend to have a consensual understanding of the notion of gender, and they often use the following expression: 'women and men have as many rights as they have duties'. As Human Rights Feminists focus on the public domain, most do not articulate a gender discourse that elaborates their understanding of women's rights issues and gender norms. In our interviews, while remaining vague in their definition of women's rights, Human Rights Feminists all preferred to use the word 'adala [justice] or insaf [fairness] instead of musawa [equality]. For example, Lamia I., 56, is a retired lawyer, a mother of five, and a prominent member of al-Rafidain Women's Coalition (RWC). She explains her vision of political activism and her notion of gender and women's rights activism:

I was asked by three different political parties to run for them, but I refused. I said that I want to remain an independent civil society women's activist. My idea is to create a women's party, but there is no group that supports this idea. Part of me believes that this is the future. [...] We at the organization, we worked a lot on

$630 \%$ in Iraqi Kurdistan. 
CEDAW in awareness-raising among women, in encouraging them to participate in political life. We also worked a lot on the constitution, and on lobbying to preserve Act No. 188 of the personal status code and reform it in a way that aligns Iraq with international conventions of human rights. [...] In terms of women's rights and the notion of gender, I think that we have to gather Western and Eastern views, because the best things are found in the middle ground. Very often, people tell me that I hold the stick from the middle, I am not very liberal [she points to her hijab] or fundamentalist. I think that the golden mean is the best thing. There are some organisations, very very few, they can be counted on one hand, that demand full equality. But most women's organisations are demanding reasonable things. We are asking for the implementation of the concept of gender. Then, there are secondary things, like we aren't demanding equality in the way men and women dress. We are demanding equality in ideas, work opportunities, and even the domestic sphere; we are demanding that domestic work should not only be on women's shoulders.

Lamia's profile and her pragmatic feminist views are very common among civil society women activists. Like most Human Rights Feminists I met, Lamia prefers to stay away from political parties and remains an independent woman activist. However, she is very close to many women representatives, such as parliamentarians and members of provincial councils, who provide her organisation with support and help her claims and demands reach governmental institutions. Like the majority of Iraqi women activists, Lamia does not tackle issues of sexuality, which she considers 'too radical', and she promotes the nuclear middle-class family framework.

\section{Islamist Activists}

There are three different profiles of Islamist activists: Sunni and Shi'a Islamists in Arab Iraq, and Kurdish Islamists in Iraqi Kurdistan (mostly Sunni but also Faili). Sunni Islamists in Arab Iraq stand alongside secular and non-religiously-exclusive women's groups, especially in their rejection of Article 41 of the Constitution and of any sectarian-based questioning of the PSC, such as the most recent Ja'fari Law proposition. However, Sunni Islamists' readings of issues related to gender and Islam are quite similar to the Shi'a Islamist ones. Thus, as my previous work on the mobilisation around the PSC has shown (Ali 2017; 2018), both Shi'a and Sunni Islamists agree on a general and loose reading of 'women's rights in Islam' characterised by a modern, middle-class, patriarchal understanding of women's issues and gender norms. Although both Sunni and Shi'a Islamists consider the PSC a fair and acceptable law, they also deem certain issues - such as polygamy and unequal shares in inheritance - as 'untouchable' issues. For them, these issues are governed by the 'Law of God' - shari'a - and cannot be questioned. Some are more conservative than others regarding women's dress and 
gender relations; for example, some consider the wearing of the 'abaya or jubba, in addition to the hijab, essential. Others consider issues of clothing to be secondary and focus in their discourse on matters of religious practice that are less gendered, such as promoting both education and political activism as 'religious duties'.

However, all Islamist women activists in Iraq also simultaneously use human rights conventions, such as CEDAW and SCR 1325, and consider them valid so long as 'the principles of shari'a' are not questioned. Thus, their use of international human rights conventions and the UN regime of women's rights is loose and ambiguous. Sallama A. is a prominent Shi'a Islamist, and the discourse she uses on women's rights is very common among Islamists in Iraq. After praising Islam for the 'perfect' and 'ideal' status it reserves for women, she tackles issues of polygamy and inheritance and the notion of qiwama [male dominance]:

Well polygamy, you know, Islam allows it, but does not promote it. On the contrary, Islam maximally limits polygamy. If the law was easy to implement, a woman could say in her marriage contract that she refuses to let her husband to take a second wife. [...] Regarding inheritance, we have an economic vision in Islam, and we would be very happy and at peace if this vision was implemented. The problem is not Islam, it is the bad interpretation and implementation of Islam. We think that a woman should not bear financial responsibility for her household, and that she has the right to keep her money and wealth for herself. The problem in Arab society is that women work outside, and then they look after the household and raise the children. And men in all of that, what do they do?

Sallama's words can be defined as a modern patriarchal perspective on gender relations, built upon the ideal of a middle-class family, in which women can be exempt from 'working outside' the home because men are supposed to be financially and morally in charge of the household. In this ideal, women's roles within the family are primarily to bear children and manage the household. Sallama's modern understanding of issues related to gender and Islam represents a common trend among Shi'a and Sunni Islamists; such an understanding is representative of the transnational Islamist discourses that emerged in the 1970s in the Middle East (Burgat 1996; Göle 1993; Hatem 1998, 1993). However, her argumentation is also very common among nonIslamist women activists when they are asked about issues related to gender and Islam. As Abu-Lughod (1998) and Hatem $(1994,2005)$ show, the nuclear, patriarchal, bourgeois family model is common among both Islamist and non-Islamist women activists across the Middle East. Although nuances exist among Islamist activists in Iraq, for example, some are more closely aligned with Muslim Feminist discourses on gender and Islam than others, they all share with Human Rights Feminists a desire not 
to address issues of sexuality. While Human Rights Feminists generally stay silent on the matter, unwilling to provoke the hegemonic social and religious conservatism of Iraqi society, Islamist women advocate for the defence of the heterosexual, patriarchal nuclear family and for containing sexuality within the framework of marriage.

More generally, Islamist women's activism is characterised by a focus on issues related to women's political participation and empowerment within the spheres of work and education, as well as on concrete humanitarian support provided through extensive charity networks. Rather than articulating a clear gender discourse, Islamist activists in Iraq have developed a loose and general rhetoric on 'women's rights in Islam', which focuses on the role of women in the political sphere, and they dedicate most of their time to humanitarian, welfare, and social work. In addition to activities alongside other women's organisations, such as 'democracy' and 'women's empowerment' trainings, Islamist women's groups are involved on the ground in a wide range of activities that cover nearly all aspects of women's lives. Thus, Hawa'ona (the Muslim Women's Organisation in Iraq), which is affiliated to the Shi'a Islamic Supreme Council of Iraq, provided activities for a significant number of women, such as literacy, tutoring for schoolgirls, sewing, and media and computer trainings. According to Hawa'ona's report, between 2004 and 2007 their activities and lectures on 'graciousness' and 'aesthetics', providing women with advice on dressing, haircuts, and 'beauty'-related activities, were far more important than their figh [religious jurisprudence] lectures. As a significant example, their report indicates that between 2004 and 2007, they organised 24 figh lectures that were attended by 290 women, 37 lectures on graciousness attended by 1386 women, and 98 aesthetics sessions attended by 588 women. The organisation, like other Islamist groups, financially supports young couples and helps them buy essential furniture. They also facilitate marriages, through such activities as organising collective weddings ceremonies. Although all their activities are framed within a specific religious discourse, such organisations are very pragmatic on the ground and seek to provide concrete answers to the population's needs. Thus, it is revealing that such organisations would prioritise aesthetics and beauty classes over figh or proper Islamic formations. Among the groups I observed, the lectures and events always tried to answer the genuine and concrete needs of its audience, from advice on women's health to marriage coaching.

An Islamist woman activist working in one of Baghdad's popular neighbourhoods insisted on the importance of addressing the basic and essential needs of women and families before proposing any kind of training on religious or women's rights issues:

Our organisation has to begin with urgent matters. We are taking care of the people in need. Every day we have women coming to our offices, they are so poor and they have children to feed. This woman comes to ask for help for her 
survival, not to listen to a conference or something theoretical. This is what I say to other civil society organisations: "how do you want to promote democracy and progress in our society when you cannot provide for the basic everyday needs of the people?' We first help them concretely and then we propose that they listen to our ideas about political activism and Islam.

Islamist activists can be characterised as conservative in terms of gender norms and representations, as most promote a patriarchal understanding of women's legal rights within an ideal patriarchal family. Nevertheless, their activism is deployed through the social and welfare support provided to women and families, and especially through charities dedicated to orphans, widows, and the elderly. However, the gender discourse of Islamist women is loose and is framed in the terms of both shari'a and the UN regime of rights, and its ambiguity allows for nuances that can go as far as a Human Rights Feminist repertoire. Thus, I argue that they are a reflection of the hegemony of religious conservatism in Iraqi society, as much as they actively reproduce it.

\section{Muslim Feminists}

Most women activists that can be defined as Muslim/Islamic Feminists are not Islamists women activists, but are more often women involved in 'secular' organisations who, by personal conviction or as a pragmatic strategy, see using anti-patriarchal readings of Muslim jurisprudences, sacred texts, and orthodox religious discourses as an important tool with which to advocate for women's rights and equality. In my interviews, all such activists preferred the word musawa [equality] to 'adala [justice] or insaf [fairness] in their advocacy for women's rights; their demands for reform of the PSC were similar to those advocated by Human Rights Feminists. The difference between Muslim Feminists and Human Rights Feminists lies in the latter's choice both to leave the sphere of religious jurisprudence to religious scholars and to base their advocacy exclusively on human rights conventions and the UN regime of rights. 'Islam' or 'Muslim culture' is advocated by Human Rights Feminists mostly as part of Iraqi culture, but not as a sphere of engagement. As the PSC is a figh-based law, many Human Rights Feminists turned to Muslim Feminist discourses as a necessary strategic tool to promote egalitarian readings of the law. Nevertheless, they avoid getting involved in the religious debates and prefer consulting and seeking the support of religious scholars over delving into the jurisprudence themselves.

Samya A., belongs to a Kurdish Islamist political party, she considers herself a Muslim Feminist. Samya articulates both a human rights repertoire and feminist understanding of religious thought and jurisprudence. She criticises dominant Islamic thought for being patriarchal and having betrayed the essential 'egalitarian message' of Islam and called for a re-reading of religious texts inspired by an egalitarian understanding of gender. 
Islamic/Muslim feminist movements have emerged as transnational intellectual dynamics in North America and Europe for about two decades, proposing anti-patriarchal readings of religious texts (Qur'an and Sunna) and figh. The use of ijtihad is, according to them, one of the main tools to implement reform of the patriarchal figh. In its pietist forms, Muslim feminism also challenges normative readings of modernity and proposes alternative modern identities grounded in the intersection of the dynamics of faith and pluralistic notions of womanhood (Ali 2012). In Muslim majority countries, Muslim feminisms are expressed in a different context - one marked by the hegemony of Islamisation, sharia-based personal laws, and, in some, the power of conservative Islamists. Thus, Muslim feminist rhetoric imposed itself in a context where the law itself, and the overall cultural climate, is Islamised. For many women's rights activists, the use of Muslim feminist rhetoric is mainly a matter of strategy, as the call for the secularisation of law proves difficult when conservative religious discourse is hegemonic.

However, some Iraqi women activists - mostly non-Islamists, but also some Islamists such as Samya A. - have developed a Muslim feminist standpoint similar to those that developed in Malaysia (Anwar 2012), Egypt (Abou Bakr 2012), and Iran (MirHosseini 2000, 2011). Without constituting a proper organisation, like Sisters in Islam in Malaysia, or being part of a transnational Muslim feminist movement, such as Musawah, these individuals have developed a feminist understanding of Islamic thought and jurisprudence and define their activism as such.

Women who stand between religious and non-religious activism could also be called Muslim Feminists. Bashaer B., 45, is neither an Islamist woman activist like Samyah A., despite the fact that she is from a religious Najafi family, nor a secular woman activist like Amel F. Rather, Bashaer is a Muslim feminist thinker, has a PhD in Law Philosophy from Kufa University, and is involved in politics as an independent parliamentarian and prominent activist. Bashaer's views on Islam are very similar to the perspective adopted by prominent and controversial Shi'a religious scholar Ahmed al-Gubenchi. In al-Mar'a, al-Mafahim wal-Huquq [Woman, Concepts and Rights], alGubenchi developed what could be called the first Iraqi Muslim Feminist discourse (2009), advocating for a radical reform of Muslim thought and jurisprudence that goes 'back to the essential egalitarian message of Islam'. Bashaer and Ahmed al-Gubenchi are often invited by various civil society groups to talk about the 'rights of women in Islam' from their Muslim Feminist standpoint. Despite being considered unorthodox by many conservative Islamists, they have managed to gain trust and consideration from Islamists and non-Islamists alike. Within Islamists spheres, they are often considered 'liberals'; within secular spheres, they are deemed 'religious'. However, Bashaer and Ahmed al-Gubenchi occupy a third space in-between Islamist and secular activists, as they employ a conflicting repertoire of discourses based on an egalitarian reading of women and gender issues within the framework of religion. 
Muslim Feminists in Iraq do not represent a coherent group or network, such as those found in Egypt, Iran, or Malaysia, and their Muslim Feminist stance does not constitute a proper agenda. Believing that gender equality is embedded within the 'message of Islam, which has been corrupted and must be radically reformed', is a widespread opinion among Iraqi women activists, including among Human Rights, Leftist and Radical Feminists. Nevertheless, Muslim Feminists believe the religious argument to be a useful and valid tool of advocacy for women's rights in the context of Iraq; Human Rights, Leftist and Radical Feminists, on the other hand, do not consider religious argumentation as an essential strategic tool in their activism. However, even if Muslim Feminists engage in religious debate on private matters - something that Human Rights Feminists refuse to do - and consider advocacy for women's rights in the public sphere to be insufficient - something that Islamist Feminists essentially do - Muslim Feminists in Iraq do not tackle issues of sexuality, as they choose to stay within the lines of what they call the 'culturally acceptable'.

\section{Leftist and Radical Feminists}

Leftist and Radical Feminists advocate for the most radical understanding of gender equality and women's rights. Many Leftist and Radical Feminists are affiliated with the Iraqi Women's League (IWL) and are close to the Iraqi Communist Party; others are active within social and development organisations, such as al-Amel. For example, the Organisation for Women's Freedom in Iraq (OWFI), which falls into this category, has members who are close to the Worker-Communist Party and members who are independent activists. Several prominent female intellectuals and scholars are Radical Feminists. However, the existing scholarship on the matter is very thin, and most such intellectuals deplore the lack of theoretical material for developing proper feminist thinking and scholarship in Iraq.

OWFI is one of the most radical women's organisations in Iraq. It defines itself as leftist, feminist, and anti-imperialist. Through its journal, Jaridat al-Musawat, OWFI advocates for gender equality and is one of the few organisations tackling issues of prostitution, sexual violence, and homophobia. ${ }^{7}$ OWFI offers help and support to women victims of sexual violence, forced prostitution, and incarceration. The OWFI activists I interviewed were the most outspoken about women's sexual freedom, sexual violence, and homophobia. Very critical of Islamist parties, they advocate for the complete secularisation of the PSC. OWFI activists were not only critical of Islamists, they seemed to address their critique at religion itself. OWFI is the only organisation that has opened shelters for women victims of abuse, which are still illegal in Arab Iraq, despite being sponsored by the government in Iraqi Kurdistan.

7 See, for example, Jaridat al-Musawat, 8 March 2012, No. 9, Year 9, p. 6. 
Since the invasion of Mosul, OWFI has also opened shelters for women and children victims of violence and sexual abuse at the hands of ISIS soldiers.

Many leftist activists I met in Iraq, despite not being involved in gender-specific organisations, developed a radical understanding of gender equality and women's issues within the framework of class-based inequalities. Thus, these leftist activists consider the questioning of patriarchy as one essential dimension of their struggle for social justice. Such was the case for the women activists I met who are involved in social and development organisations, such as al-Amal or Tammuz Organization for Social Development. More generally, many members of the IVL are Leftist Feminists, and they have developed an understanding of social justice and equality that considers gender equality as the core of their project for social change. The difference between most Leftist Feminists and Radical Feminists, who are often leftist activists as well, is that the Leftist Feminists' discourse about sexuality is more limited and does not cross the boundaries of what they consider 'acceptable to society'. Thus, although Leftist and Radical Feminists are often in agreement about sexual freedom and homophobia, Radical Feminists tend to be more outspoken about these issues. Nevertheless, Leftist and Radical Feminists both avoid debates about religion; on this matter, they stand alongside Human Rights Feminists, as they consider religion to be a part of 'culture' but do not engage with religious issues per se.

Iman A., 42, is a sociologist and a researcher at Baghdad University; she is also one of the most radical feminists I met in Iraq. Before the fall of the regime, Iman had produced several studies on gender for the GFIW. Since its collapse, she has been very active around gender and women's rights issues. Along with other Iraqi scholars, Iman founded the Iraqiyat Studies Center, which is dedicated to gender issues and was very active until 2010. Iman also published several articles and studies on the condition of women since the invasion and occupation in sociological journals. She speaks about getting involved in women's organisations and networks after the fall of the regime, and the fact that she was one of the few people who had been trained in gender matters from the GFIW. She explains her views on gender equality and the implementation of such views in Iraq:

I advocate for total equality. I am very familiar with and close to what is called the third wave of feminism, demanding the questioning of the very meaning of gender hierarchies and differences. Until very recently, I was living a life consistent with my ideas. I chose neutral clothes, neither feminine nor masculine, and I promoted these kinds of ideas. But here, you know, we cannot demand these kinds of things, it's not the right time. And I really believe that ideas and laws that do not follow the development of society are not useful and won't provide anything. In the West, feminism followed social, economic, and life development. I respect the thought 
developed by third-wave feminism, but it is really not the time to implement it in Iraq. When we reach all the steps achieved by first- and second-wave feminism in the West, especially in terms of feminist activism, then we can start talking about questioning gender divisions. At the moment, we want to advocate for human rights for women, for women's humanity to be acknowledged. Tribal mores are very hard on women, there has been an enormous regression in women's conditions in Iraq. Now, you know, the fact that a young girl is escorted by her brother to go to university, or that she uses khat la private driver shared with other people] to move around, this impacts her very freedom of movement.

When I met her in 2012, Iman spoke about her two marriages. She was first married at the age of 35, but this marriage did not work. She got married again two years later, and now has a young child. She explained how married life forces her to live in a complete contradiction to her beliefs. Despite the fact that Iman is financially in charge of her household, she is also in charge of all domestic work and takes care of her baby on her own. Iman added that her husband only washes the dishes on holidays and thinks that he should be 'celebrated for it'. Iman's depiction of living a life that contradicts her beliefs in gender equality is common among many activists I met.

\section{Conclusion: Contextualising Feminisms}

In presenting elements that characterise the concrete realities of Iraqi women activists' lives, I seek to show the necessity of analysing different feminisms in relation to the concrete realities in which they are expressed. Notions of 'morality' and 'respectability' are framed by multiple forms of conservatisms. Thus, Iraqi women activists' 'multiple moral rubrics' are characterised by social, political, and religious conservatisms that shape patriarchal gender norms and relations, impacting women's everyday lives. Thus, while some women activists, such as Muslim Feminists, use a religious argumentation to advocate for women's rights, others use it as a tool in a context marked by shari'abased laws and the hegemonic power of conservative Islamist parties.

While some women choose to put aside religious references and others choose to Islamise their defence of women's rights, most activists, either for pragmatic reasons or due to personal beliefs, take an overlapping stance: defending social equality within the limits of cultural or religious specificities. Although the dominant discourse reproduces the West/Arab-Muslim dichotomy by claiming to defend women's rights in an 'essentially different' way than the West, a minority of women seek to go beyond the dichotomy by using Islam as a way to claim the indigenous nature and authenticity of their stance. Thus, women activists' positions in Iraq are complex and multifaceted: they define themselves differently, or choose not to define themselves at 
all, within the secular/Islamist, non-religious/religious binaries. This overlapping stance is comparable to women's rights activism in the Middle East more generally, which is the product of modernist, nationalist, and developmentalist rhetoric in contexts where political Islam represents the hegemonic discourse (Abu-Lughod 1998; Hatem 2005, 1994; Charrad 2011, 2001).

Thinking beyond these categories and paying attention to the in-betweenness is essential to understand issues of women, gender, and feminisms in the Iraqi context. The intersections between local and global discourses and practices are central to understanding Iraqi women activists' overlapping stances, in addition to the evolution of gender politics resulting directly from the political, economic, and social realities that transformed Iraqi society. The NGOisation of women's groups contributed to the homogenisation of their activism as focused on tathqif [culture-raising] and taw'iyya [awareness-raising].

Along the same lines of the analyses by Abu Lughod (1998) and Hatem (1994, 2005), I have also shown that in terms of social background (urban, educated, and upper or middle class), agenda, grassroots work, and representations of and discourses on women's rights - there is no fundamental difference between most secular-oriented and Islamist women's rights activists in Iraq. Many Islamists have appropriated modernist conceptualisations of women's roles in society, marriage relations, and the family, thereby competing with both conservative modernists and progressive political activists over these issues. In a context of exacerbated identity politics, most secularists and Islamists engage in the post-colonial 'authenticity' debate; only a minority of activists strive to go beyond it. At the crossroads of local and global discourses, the hegemony of religious conservatism and the NGOisation of activism constitutes the framework for advocating women's legal rights. Thus, no stance is strictly Islamist, Muslim, or secular feminist, as most activists are simultaneously invoking notions of respectability, moral references (justified by Islam or culture), and the frame of international human rights.

\section{References}

Abu-Lughod, L. (ed.). 1998. Remaking Women: Feminism and Modernity in the Middle East. Princeton University Press.

Ahmed, L. 2011. A Quiet Revolution. The Veil's Resurgence from the Middle East to America. New Haven: Yale University Press.

Ahmed, L. 1992. Women and Gender in Islam. Historical Roots of a Modern Debate. New Haven: Yale University Press.

Al-Ali, N. 2007. Iraqi Women. Untold Stories from 1948 to the Present. London: Zed Books.

Al-Ali, N. 2000. Secularism, Gender and the State in the Middle East. The Egyptian

Women's Movements. Cambridge: Cambridge University Press. 
Al-Ali, N., Pratt, N. 2009. What Kind of Liberation? Women and the Occupation of Iraq. Berkeley: University of California Press.

Al-Gubenchi, A. 2009. Al-Mar'a, al-Mefahim wal Huquq. Qira'e jedida li Qedaya al-Mar'a fi al-Khitab al-Dini. Beirut: Al-intishar al-'arabi.

Al-Jawaheri, Y. H. 2008. Women in Iraq. The Gender Impact of International Sanctions. London: I. B. Tauris.

Ali, Z. 2018. Women and Gender in Iraq: Between Nation-Building and Fragmentation. Cambridge: Cambridge University Press.

Ali, Z. 2017. 'The Fragmentation of Gender in Post-Invasion Iraq.' in A. Ghazal, J. Hanssen (eds.). The Oxford Handbook of Contemporary Middle-Eastern and North African History. Oxford Handbooks Online.

Ali, Z. 2012. Féminismes Islamiques. Paris: La Fabrique.

Arato, A. 2009. Constitution Making Under Occupation. The Politics of Imposed Revolution in Iraq. New York, Chichester: Columbia University Press.

Asad, T. 2003. Formations of the Secular. Christianity, Islam, Modernity. Stanford: Stanford University Press.

Badran, M. 1995. Feminists, Islam, and Nation: Gender and the Making of Modern Egypt. Princeton: Princeton University Press.

Burgat, F. 1996. L'islamisme en face. Paris: La Découverte.

Burgat, F. 2005. L'islamisme à I'heure d'Al-Qaida. Paris: La Découverte.

Charrad M. M. 2011. 'Gender in the Middle East: Islam, State, Agency.' Annual Review of Sociology, Vol. 37: 417-437. https://doi.org/10.1146/annurev.soc.012809.102554.

Charrad M. M. 2001 States and Women's Rights: The Making of Postcolonial Tunisia, Algeria and Morocco. Berkeley: University of California Press.

Damaluji, M. 2010. 'Securing Democracy in Iraq: Sectarian Politics and Segregation in Baghdad, 2003-2007.' Traditional Dwellings and Settlements Review, Vol. 21, No. 2: 71-87.

Deeb, L. 2006. An Enchanted Modern: Gender and Public Piety in Shi'i Lebanon. Princeton: Princeton University Press.

Deeb, L., Harb, M. 2013. Leisurely Islam: Negotiating Geography and Morality in Shi'ite South Beirut. Princeton: Princeton University Press.

Dodge, T. 2013. Iraq - From War to a New Authoritarianism. Adelphi Series. London: Routledge.

Dodge, T. 2005. Iraq's Future: the Aftermath of Regime Change. Adelphi Papers, 372. Abingdon: Routledge for the International Institute for Strategic Studies.

Hatem, M. 2005. 'Secularist and Islamist Discourses on Modernity in Egypt and the Evolution of the Post-colonial Nation-State.' Pp. 263-294 in Moghissi, H. (ed.). Women and Islam: Images and Realities. Abingdon: Taylor \& Francis.

Hatem, M. 1998. 'The Secularist and Islamist Discourses on Modernity in Egypt and the Evolution of the Post-Colonial Nation-State.' Pp. 85-99 in Haddad, Y., Esposito, J. (eds.). Islam, Gender and Social Change. Baltimore: Oxford University Press.

Hatem, M. 1994. 'Egyptian Discourses on Gender and Political Liberalization: Do Secularist and Islamist Views Really Differ?' Middle East Journal, Vol. 48, No. 4: 661-676. 
Hatem, M. 1993. 'Toward the Development of Post-Islamist and Post-Nationalist Feminist Discourses in the Middle East.' Pp. 29-48 in Tucker, J. E. (ed.). Arab Women: Old Boundaries, New Frontiers. Bloomington: Indiana University Press.

Haddad, F. 2014. Sectarianism in Iraq: Antagonistic Visions of Unity. Oxford: Oxford University Press.

Ismael, Y., Ismael, S. 2015. Iraq in the Twenty-First Century. Regime Change and the Making of a Failed State. London and New York: Routledge.

Jayawardena, K. 1986. Feminism and Nationalism in the Third World. London: Zed Books.

Kandiyoti, D. 2007. 'Between the Hammer and the Anvil: Post-conflict Reconstruction, Islam and Women's Rights.' Third World Quarterly, Vol. 28, No. 3: 503-517.

Karam, A. 1998. Women, Islamisms and the State. Contemporary Feminisms in Egypt. Palgrave MacMillan Press.

Mahmood, S. 2005. Politics of Piety. The Islamic Revival and the Feminist Subject. Princeton: Princeton University Press.

Mir-Hosseini, Z. 2011. 'Beyond Islam vs Feminism.' Institute of Development Studies Bulletin, Vol. 42, No. 1: 67-77.

Mir-Hosseini, Z. 2000. Islam and Gender. The Religious Debate in Contemporary Iran. London: I. B. Tauris.

Najmabadi, A. 2000. '(Un)Veiling Feminism.' Social Text 64, Vol. 18, No. 3: 29-45.

Reilly, N. 2011. 'Rethinking the Interplay of Feminism and Secularism in a Neo-secular Age.' Feminist Review, Vol. 97, No. 1: 5-31.

Salime, Z. 2011. Between Feminism and Islam. Human Rights and Sharia Law in Morocco. Minneapolis: University of Minnesota Press. Available from: http://www.jstor.org/ stable/10.5749/j.ctttsgkb.

Sassoon, J. 2012. 'The Brain Drain in Iraq after the 2003 Invasion in Writing the Modern History of Iraq.' Pp. 379-389 in Tejtel, J., Sluglett, P., Bocco, R., Bozarslan, H. (eds.). Writing the Modern History of Iraq. Historiographical and Political Challenges. Hackensack, London: World Scientific Publishing.

Zubaida, S. 2011. Beyond Islam: A New Understanding of the Middle East. London: I. B. Tauris.

Zubaida, S. 1989. Islam, the People and the State. London: Routledge.

@ BY-NC Zahra Ali, 2019.

(c) BY-NC Institute of Sociology of the Czech Academy of Sciences, 2019.

Zahra Ali is a sociologist and Assistant Professor of Sociology at Rutgers University. Her research explores the dynamics of women and gender, social and political movements in relation to Islam(s) and the Middle East, and contexts of war and conflicts with a focus on contemporary Iraq. She is the author of Women and Gender in Iraq: Between NationBuilding and Fragmentation published by Cambridge University Press in 2018. Contact email: z.ali@rutgers.edu. 